\title{
Epidemiological aspects of scorpionic accidents in a municipality in Brazil's northeastern
}

\author{
Aspectos epidemiológicos dos acidentes escorpiônicos em um munícipio do \\ nordeste brasileiro
}

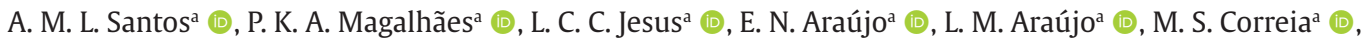

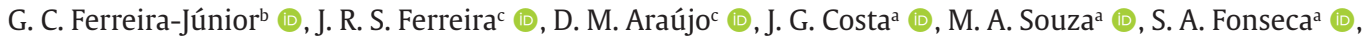 \\ J. M. S. J. Pavão ${ }^{\mathrm{a}}$ (D), A. F. dos Santos ${ }^{\mathrm{a}, \mathrm{d}}$ (D) and T. J. Matos-Rochaa,c* (D)
}

a Centro Universitário Cesmac, Maceió, AL, Brasil

${ }^{\mathrm{b}}$ Instituto Federal de Educação, Ciência e Tecnologia do Acre - IFAC, Xapuri, AC, Brasil

' Universidade Estadual de Ciências da Saúde de Alagoas - UNCISAL, Maceió, AL, Brasil

${ }^{\mathrm{d} U n i v e r s i d a d e ~ E s t a d u a l ~ d e ~ A l a g o a s ~-~ U N E A L, ~ A r a p i r a c a, ~ A L, ~ B r a s i l ~}$

\begin{abstract}
Scorpionic accidents are a major public health problem due to the high occurrence with potential seriousness. In this manner, the research aimed to analyze the occurrence of scorpionic accidents in a municipality in the northeastern of Brazil. An exploratory, descriptive study was made, with a quantitative approach, using secondary data which was gotten from the Notifiable Diseases Information System (SINAN), from 2008 to 2018. Data such as neighborhood, presence of street markets were also used, and the existence of sanitation and climatic data such as temperature and season. Geoprocessing was used to identify possible changes in the environment. In the analyzed period, 9,330 cases of scorpion accidents were recorded, with an average of 848 annual notifications. Scorpionic accidents occurred more frequently in women (5,686; 60.94\%). Individuals aged 20 to 29 years $(1.727 ; 18.51 \%)$ were more frequent to scorpion stings. Regarding the body parts where the stings were made, the highlights were on the foot $(3.515 ; 37.67 \%)$ followed by the hand $(2.818 ; 30.20 \%)$. No statistically significant relation was observed between climatic factors and scorpionic accidents. However, the high number of cases of scorpionic accidents was observed in the last 11 years studied. It was evident that during the study period there was no statistical relationship when climatic factors were correlated to scorpionic accidents. On its turn, when it was verified the results of the geoprocessing analysis, it was seen that anthropic factors have been motivating the potentiation of the occurrence of these accidents.
\end{abstract}

Keywords: arachnids, scorpions, scorpion sting, human envenoming.

\section{Resumo}

Os acidentes escorpiônicos apresentam-se como um grande problema de saúde pública em virtude da grande ocorrência com potencial gravidade. Nesse sentido, o trabalho teve como objetivo analisar a ocorrência de acidentes escorpiônicos em um município do nordeste brasileiro. Foi realizado um estudo descritivo, de caráter exploratório, com abordagem quantitativa em que foram utilizados dados secundários obtidos no Sistema de Informação de Agravos de Notificação (SINAN), no período de 2008 a 2018. Também foram utilizados dados como bairro, presença de feiras livres e a existência de saneamento básico e dados climáticos como temperatura e estação do ano. $O$ geoprocessamento foi utilizado para identificar as possíveis alterações no ambiente. No período analisado, foram registrados 9,330 casos de acidentes com escorpião, com média de 848 notificações anuais. Os acidentes escorpiônicos ocorreram com mais frequência em mulheres (5,686; 60,94\%). Em indivíduos na faixa etária de 20 a 29 anos $(1,727 ; 18,51 \%)$ foram mais frequentes a picada de escorpião. Com relação ao local das picadas destacaram-se o pé $(3,515 ; 37,67 \%)$, seguido da mão $(2,818 ; 30,20 \%)$. Não foi observada relação estatisticamente significativa entre os fatores clímáticos e os acidentes escorpiônicos. Foi observado elevado número de casos de acidentes escorpiônicos nos últimos 11 anos estudados. Ficou evidente que durante o período de estudo não existiu relação estatística quando se correlacionou fatores climáticos aos acidentes escorpiônicos. Por sua vez, ao verificar os resultados da análise de geoprocessamento foi visto que fatores antrópicos têm sido motivadores da potencialização da ocorrência desses acidentes.

Palavras-chave: aracnídeos, escorpiões, picada de escorpiões, envenenamento humano.

*e-mail: tmatosrocha@cesmac.edu.br

Received: 15 May 2020 - Accepted: 16 October 2020 


\section{Introduction}

Scorpionic accidents caused by the inoculation of the toxin through the telson located at the tail of the arthropod, is a neglected condition associated with the conditions of poverty, environmental imbalance and disinformation. The stung individuals can evolve to decease or sequelae causing temporary disability for habitual activities (Fracolli, 2017).

The degradation of the environment and disorderly growth in large urban centers, has favored the incidence of scorpionic accidents. Studies have long shown that the problem of scorpionism is strongly associated with the socioeconomic conditions of the population, as it occupies the soil and it is also related to environmental issues (Barbosa et al., 2015).

The evolutionary process allowed a wide adaptation of many scorpions groups, allowing a greater dissemination that led them to occupy from desert regions to urbanized centers (Dabo et al., 2011). The modifications promoted in ecosystems by man is one of the reasons for the invasion of these animals in the urban environment. These changes change the environmental conditions favoring the presence of some groups of these animals while another has its possibility of success is almost completely suppressed (Carvalho et al., 2011).

The increase in the number of cases of scorpionism occurs due to factors such as lack of sanitation and poor housing conditions, especially in the big cities, with two factors being indicated as the main causes of the occurrence of these animals: 1 - urban environments offer hideaway, places that are difficult to access for man and natural predators, making biological control impossible; 2 - the accumulation of garbage in cities brings roaches and other insects that are abundant food sources for spiders and scorpions (Stropa, 2010).

The cases of accidents with venomous animals started to be registered in 1988 on the Diseases Information and Notification System (SINAN). In this manner, injuries caused by snakes, spiders and scorpions started to be controlled throughout the country (IBGE, 2019). Since then, it is estimated that annually, in Brazil, more than 100 thousand cases of accidents due to venomous animal stings occur, reaching the number of 200 deaths per year, with scorpionism being one of the main factors for the incidence of such numbers (Carmo et al., 2016).

In this regard, Brazil has come to regard the cases of scorpionism as a medical-sanitary problem since the injuries caused by the stings have caused serious clinical conditions, which can even lead to death. The numbers have been increasing across the country, which is why the scientific community seeks to understand the factors that are contributing to this phenomenon (Souza and Bochner, 2019).

In the past couple years, there has been an increase in the prevalence of scorpionic accidents, in this sense, the updated epidemiological knowledge is relevant, mainly due to socio-environmental changes in the last decades, in addition, there are only a few studies with this subject in the state of Alagoas. In this manner, the present study aimed to assess the factors involved in the occurrence of these accidents in Arapiraca city.

\section{Materials and Methods}

An analytical, descriptive, observational-retrospective study was made that aimed to analyze the factors that corroborate the occurrence of scorpionism in Arapiraca, focusing on neighborhoods with the highest occurrence of scorpionic accidents.

The sample consisted of the total number of cases registered directly from the Ministry of Health's Epidemiological Investigation Forms of the Notifiable Diseases Information System (SINAN). These files refer to accidents involving venomous animals, which, since 1988 , have been mandatory notification in Brazil. For this study, only the cases that had the scorpion as an animal involved in the accident and whose victims lived in Arapiraca, between the 2008 to 2018 were selected. The data obtained at SINAN, were correlated with age, sex and location of the injury.

From the cases notified, in the aforementioned period, after checking duplicate records and checking for inconsistencies, notifications that did not have addresses for georeferencing were excluded. The data obtained were also used by SINAN as age group, gender, neighborhood and climatic data such as temperature, humidity, precipitation, those from the National Meteorological Institute (INMET).

Geoprocessing was used to identify possible changes in the environment during the study period, using a geographic database of the object area, built from satellite images and digital data made available by public agencies, namely: Municipal network (Brasil, 2017); Drainage (IBGE, 2017); Statistical data on sanitary sewage by neighborhood (Brasil, 2017) and Climatic data (INMET, 2016). These data were collected from various public administration bodies and they made them available on their internet pages, in shapefile format (SHP), or extracted from thematic maps (INMET, 2016).

In this manner, to determine the site relation among neighborhoods and vunerable areas to the scorpionism the QGIS, a Geographic Information System (SGI), was adopted and licensed under the "GNU General Public License", to support many stes formats, raster, of database and other functionalities (Casela, 2019).

From this set of digital data, digital mappings (of the urban evolution of the study area, of the distribution of sanitary sewage by neighborhood, of the occurrence of scorpionic accidents) were elaborated based on the parameters defined as relevant to the studied phenomenon identification, for the analysis and identification of risk indicators and areas in the different regions of the city, using the incidence data by neighborhood/year.

This stage of the study refers to the direct conjunction between the variables raised for the construction of the analysis of scorpionism in the municipality of Arapiraca, where the variables were related through the Dummy coding method, which indicates the presence or absence of an attribute, in which the original variables are transformed into artificial ones assuming values of 0 or 1 , where zero indicates the absence of an attribute and one, its presence (Gomes, 2012).

In view of the infeasibility of the correlation analysis when one or more of the variables has a nominal 
categorical type, therefore, it becomes necessary to transform the qualitative values into quantitative ones. Following this method, for better analysis in the software, we selected the 3 variables that presented data stratified by neighborhoods and of greater statistical relevance (Scorpionic cases, Sanitary sewage, Free Fairs) according to the table below, where: 1 - represents the presence of the characteristic of interest; 0 - represents the absence of the characteristic of interest. In this case, scorpionic accidents: 1 - Neighborhoods with more than 28 accidents; 0 - Neighborhoods with less than 28 accidents; Sewage: 1 - Neighborhoods with households with a percentage greater than $60 \%$ of inadequate sewage; 0 - Neighborhoods with less than $60 \%$ of inadequate sewage; Free Fairs: 1 - Neighborhoods with the presence of free fairs; 0 - Neighborhoods with no free fairs. Finally, with the use of QGIS, the artificial variables were superimposed, generating a coded database of binary data containing the correlation between areas with Scopianism and areas with relevant phenomena. It should be noted that the binary bases starting with 0 were grouped as areas with low/medium concentration of scorpionic cases.

The data obtained were subjected to descriptive statistics, Pearson's correlation coefficients were estimated between socioeconomic and environmental variables with the incidence of scorpions and an analysis of the trend with the time series. The Chi-square test at the level of $5 \%$ probability was also used to compare the percentages of incidence between the seasons. The analyzes were performed using the software Genes and ActionStat 3.6 (Cruz, 2016). Values of p <0.05 were considered significant.

\section{Results}

In the period between January 2008 and December $2018,9,330$ cases were notified, with an annual variation between 674 (in 2009) to 1,144 (in 2018) and an overall average of 848 notifications. The occurrence of cases was not increasing during all years, in some periods there was a decrease on the incidence followed by an increase, as in the period between 2008 and 2011. However, there were periods with increasing cases such as between 2011 and 2014 and between 2015 and 2018.

The data shows that in Arapiraca-AL the occurrence of scorpionic accidents has already exceeded one thousand cases per year. Comparing the period from 2008 to 2013, there is an increase of 152 cases, which corresponds to an increase of $21 \%$ of occurrences. The increase in cases is even more expressive when comparing the periods between the years 2013 and 2018, due to the increase of 272 cases, which represented an increase of $31 \%$ in occurrence (Table 1). During the analyzed period, it was seen that the victims were predominantly female ( $\mathrm{n}=5,686 ; 60.94 \%$ ) (Graph 1 ).

In relation to the age group (Graph 2 ), he observed that individuals aged 20 to 29 years had a higher frequency of bites ( $n=1,727 ; 18.51 \%)$, followed by the age group of 30 to 39 years $(n=1,457 ; 15.29 \%)$. The lowest
Table 1. Human accidents caused by scorpions in the municipality of Arapiraca-AL, registered by SINAN (2008-2018).

\begin{tabular}{ccrc}
\hline Year & Number of cases & \multicolumn{1}{c}{$\%$} & Rate/100.000 hab \\
\hline 2008 & 720 & 7.72 & \\
2009 & 674 & 7.22 & \\
2010 & 853 & 9.14 & 398.59 \\
2011 & 750 & 8.04 & \\
2012 & 755 & 8.09 & 346.11 \\
2013 & 872 & 9.35 & \\
2014 & 927 & 9.94 & \\
2015 & 813 & 8.71 & \\
2016 & 833 & 8.93 & 358.02 \\
2017 & 989 & 10.60 & \\
2018 & 1144 & 12.26 & 496.49 \\
Total & 9330 & 100.00 & \\
Avg & 848 & 9.09 & \\
\hline
\end{tabular}

Source: Epidemiological investigation forms / Information System for Notifiable Diseases / Ministry of Health (Brasil, 2018).

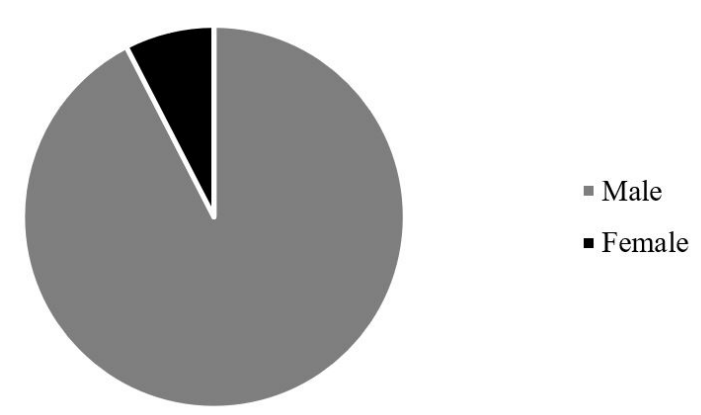

Graph 1. Number of cases of scorpion accidents (\%) registered by SINAN, stratified by sex of the patient, in the municipality of Arapiraca, AL, between 2008 and 2018.

frequency was observed in the group younger than 1 year ( $n=96 ; 0.98 \%$ ), followed by individuals over 80 years $(n=104 ; 1.11 \%)$. Graph 3 shows that the feet were the main injured part of the body $(n=3.515 ; 37.67 \%)$, followed by the hands ( $n=2.818 ; 30.20 \%$ ). There were also $11.90 \%$ of cases without description of the location of the bite $(n=1.111)$.

In order to associate the occurrence of scorpionism and the climatic variables, the incidence between the seasons was evaluated. In this manner, it was observed that there were no marked variations between seasons, showing that, in the study area, the climate has not influenced the greater or lesser occurrence of scorpions. In general, the occurrence percentages between the seasons in the period studied did not show significant variations between them, with autumn being the season with the highest number of cases $25.89 \%$ and winter with $23.53 \%$ being the season with the lowest number of cases. There was no statistical difference between 


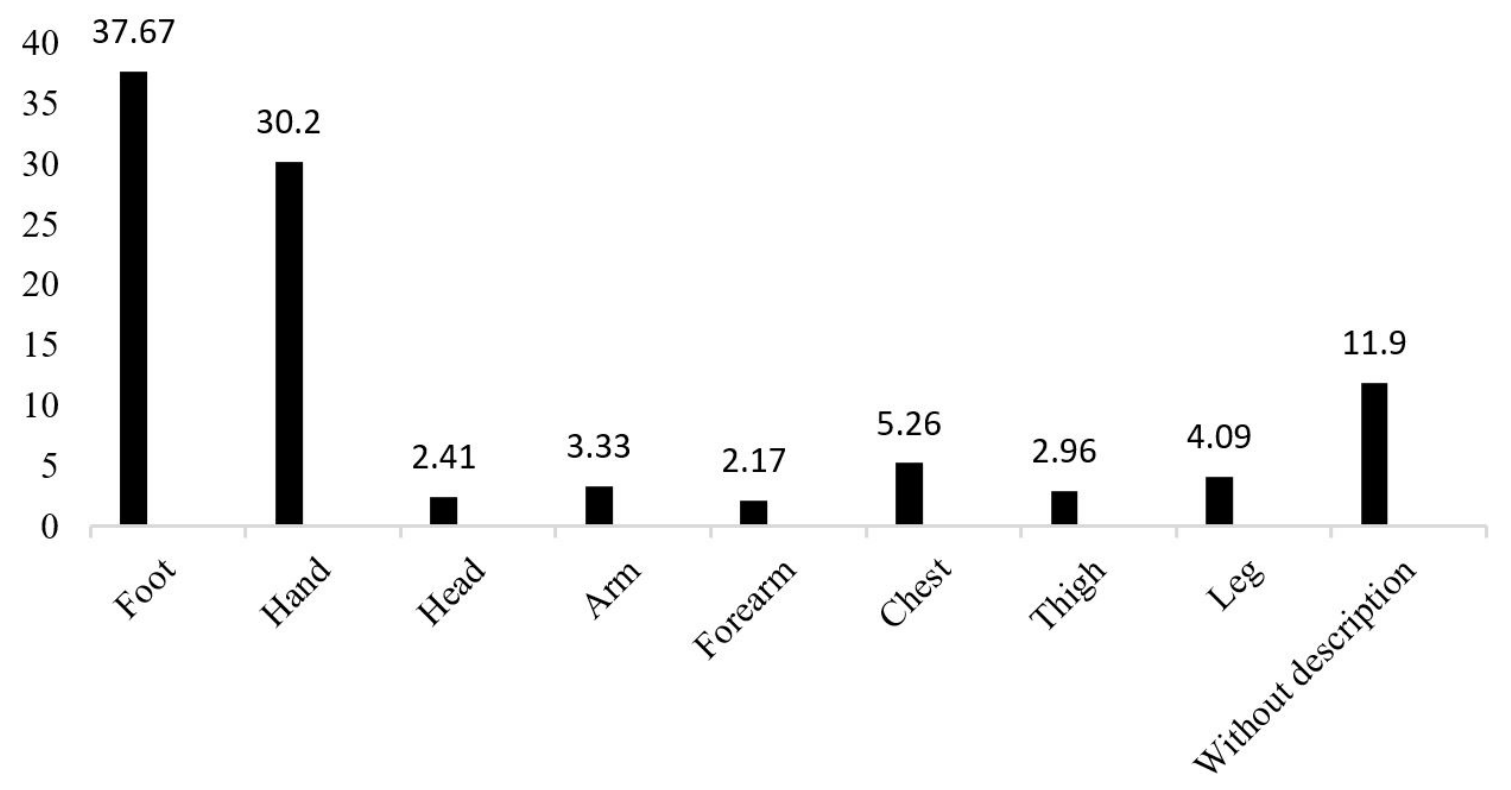

Graph 3. Occurrence of scorpion accidents recorded by SINAN (\%) in the municipality of Arapiraca, AL, in the period from 2008 to 2018 , according to the site of the injury.

the percentages of the seasons at $5 \%$ probability by the chi-square test.

Data on notifications of scorpionic accidents by neighborhood are shown in Table 2, with the Brasília and Primavera neighborhoods standing out for having presented high numbers when compared to the other neighborhoods in the city. The first registered, in 10 years, a total of 881 cases and the second presented the number of 1228 cases. Brasília neighborhood has already registered more than 100 cases of accidents per year, being them in the years of 2012, 2014 and 2018. The Primavera neighborhood has registered more than 100 occurrences per year since 2010, maintaining a high standard in its numbers.

Figure 1 shows the map with the main neighborhoods of Arapiraca and their percentage of sanitation. It appears that most neighborhoods have inadequate sanitation conditions. This map shows that the high occurrence of scorpions in Arapiraca is due to the lack of basic sanitation, 
Table 2. Average scorpion notifications by neighborhood and respective percentages for the period 2008 to 2018 in Arapiraca-AL.

\begin{tabular}{|c|c|c|}
\hline Neighborhood & NA & $\%$ \\
\hline Primavera & 147.30 & $17.37^{* *}$ \\
\hline Brasília & 105.66 & $12.46^{* *}$ \\
\hline Cacimbas & 56.82 & $6.70^{\circ}$ \\
\hline Downtown & 44.01 & 5.19 \\
\hline Canafístula & 41.21 & 4.86 \\
\hline Alto do Cruzeiro & 37.82 & 4.46 \\
\hline Baixão & 36.29 & 4.28 \\
\hline Cavaco & 31.21 & 3.68 \\
\hline Baixa Grande & 26.88 & 3.17 \\
\hline Jardim Planalto & 26.71 & 3.15 \\
\hline Caititus & 26.12 & 3.08 \\
\hline Manoel Teles & 23.66 & 2.79 \\
\hline Jardim Esperança & 22.39 & 2.64 \\
\hline São Luiz & 22.05 & 2.60 \\
\hline Eldorado & 20.61 & 2.43 \\
\hline Boa Vista & 17.38 & 2.05 \\
\hline Nova Esperança & 15.43 & 1.82 \\
\hline Ouro Preto & 15.43 & 1.82 \\
\hline Santa Esmeralda & 14.75 & 1.74 \\
\hline Jardim Tropical & 13.40 & 1.58 \\
\hline Caititus2 & 13.23 & 1.56 \\
\hline Guaribas & 10.18 & 1.20 \\
\hline Capiatã & 8.65 & 1.02 \\
\hline Novo Horizonte & 8.39 & 0.99 \\
\hline Itapoã & 8.39 & 0.99 \\
\hline Brasiliana & 7.89 & 0.93 \\
\hline Nilo Coelho & 7.21 & 0.85 \\
\hline Santa Esmeralda & 6.61 & 0.78 \\
\hline Arnon de Melo & 6.19 & 0.73 \\
\hline Verdes Campos & 5.17 & 0.61 \\
\hline Capiatã 2 & 4.58 & 0.54 \\
\hline Brasiliana 2 & 4.07 & 0.48 \\
\hline Rosa Cruz & 3.14 & 0.37 \\
\hline Teotônio Vilela & 2.63 & 0.31 \\
\hline Jardim Paineiras & 2.37 & 0.28 \\
\hline Poço Frio & 1.78 & 0.21 \\
\hline Rosa Cruz 2 & 0.93 & 0.11 \\
\hline Jardim Planalto & 0.68 & 0.08 \\
\hline Total & 848 & 100 \\
\hline Avg. & 22.32 & 2.63 \\
\hline
\end{tabular}

${ }^{*},{ }^{* *}$ Significant at $5 \%$ and $1 \%$, respectively by the Chi-Square test. $\mathrm{NA}=$ Number of accidents. which generates the presence of roaches and consequently attracts scorpions.

The neighborhoods of Arapiraca have deficient infrastructure, according to the mapping, with 21 neighborhoods characterized between 80 and $100 \%$ of inadequate sanitation, that is, $55 \%$ of the neighborhoods in the study area do not have a septic tank or are not connected to the general sewerage network, so the waste is dumped in ditches, ponds and rivers or in rudimentary cesspools. The city has only $20 \%$ of basic sanitation.

Figure 2 shows that the combination of the variables street market and the absence of sewage increases the occurrence of scorpionic accidents. It is important to highlight that other neighborhoods also had a high concentration of cases. In common to all of them, the fact that open fairs are held, an important economic activity for the city, however, without proper hygiene conditions. It was possible to check sewage close to the commercialized products as well as solid waste scattered on the streets and sidewalks of the city, highlighting blood and remains of the slaughtered animals (meat and fish).

\section{Discussion}

In the municipality of Arapiraca-AL, scorpion accidents, in the period from 2008 to 2018, presented an overall average of 848 notifications. Considering the occurrence rate per 100,000 inhabitants, it was found that the data are very high in relation to other regions such as those reported by Mesquita et al. (2015) for the period between 2002 to 2012 that were in the range of 5.13 to 31.58. Furtado et al. (2016) comments that in Ceará there was also an increase during the period from 2007 to 2013, with an average annual incidence of 18.57 cases / 100,000 inhabitants. For him, the raise can be explained by several reasons such as, for example, the disordered growth of cities, the good adaptability of scorpions in urban areas, the improvement of the notification system, and the greater environmental degradation close to cities.

The highest percentages in the occurrence of scorpion accidents occurred in woman. These findings agree with Albuquerque et al. (2004), who postulate in their study a higher proportion of injured women, justifying that this fact can occur among women due to performing, in the domestic environment, cleaning activities in places inhabited by scorpions. However, most of the literature cited refers to the higher occurrence of accidents among men, these data could be related to the search for medical care. This agrees with the descriptive data of several authors in Brazil (Zanella et al., 2018; Furtado et al., 2016; Mesquita et al., 2015); México (Calderón-Aranda et al., 1996) amd Venezuela (Maradei-Irastorza, 1999).

In this study, most of the victims of scorpionism belonged to the age group of 20 to 59 years, as has been observed in other studies conducted in Brazilian states (Dias and Barbosa, 2016; Silva et al., 2015; Reckziegel and Pinto-Junior, 2014). This group corresponds to the economically active population, with those in the third decade having the highest growth rates, which indicates a greater risk among people who perform work and 


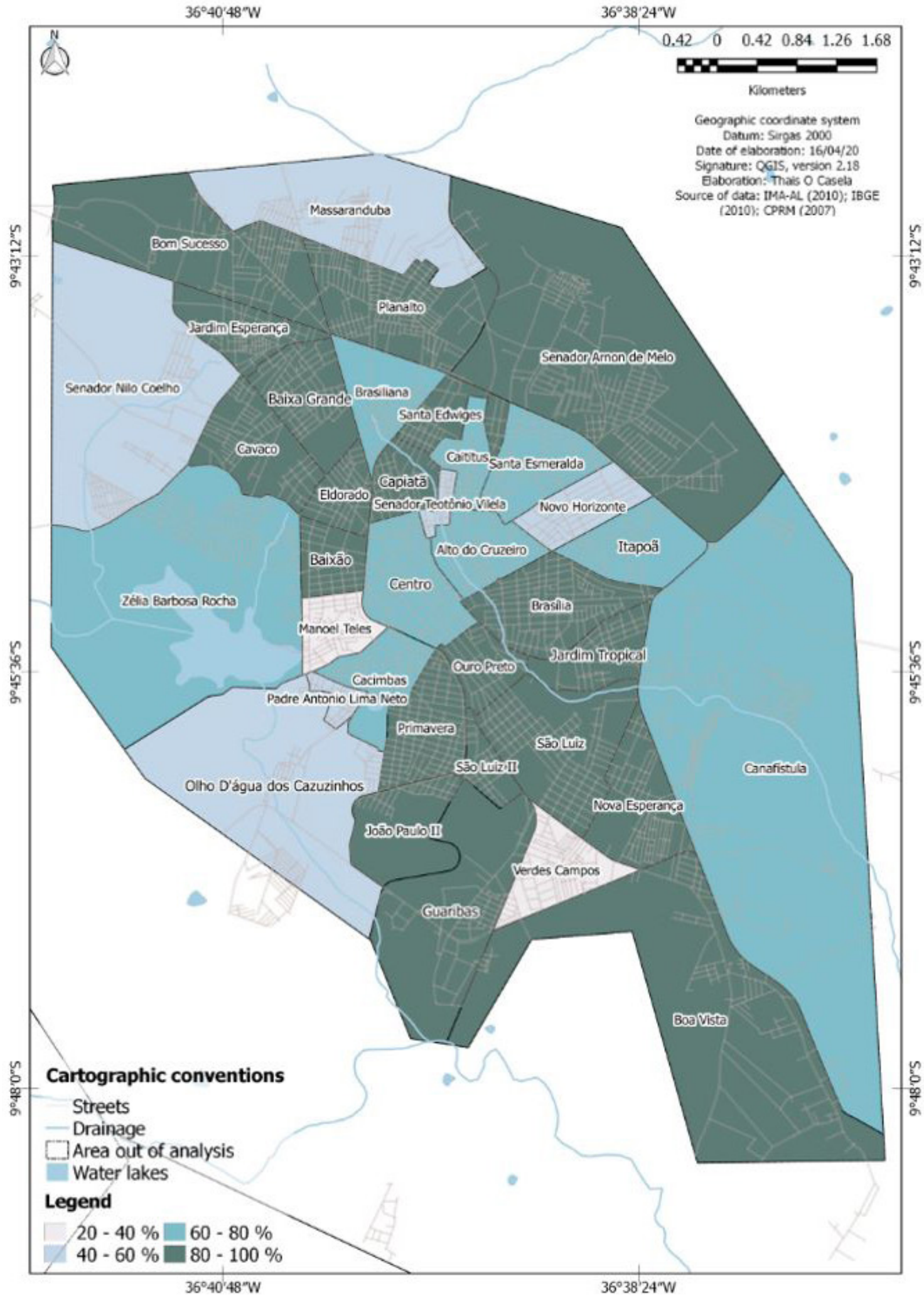

Figure 1. Percentage of households with inadequate sanitation in neighborhoods in the urban area of Arapiraca-AL, from 2008 to 2018. 


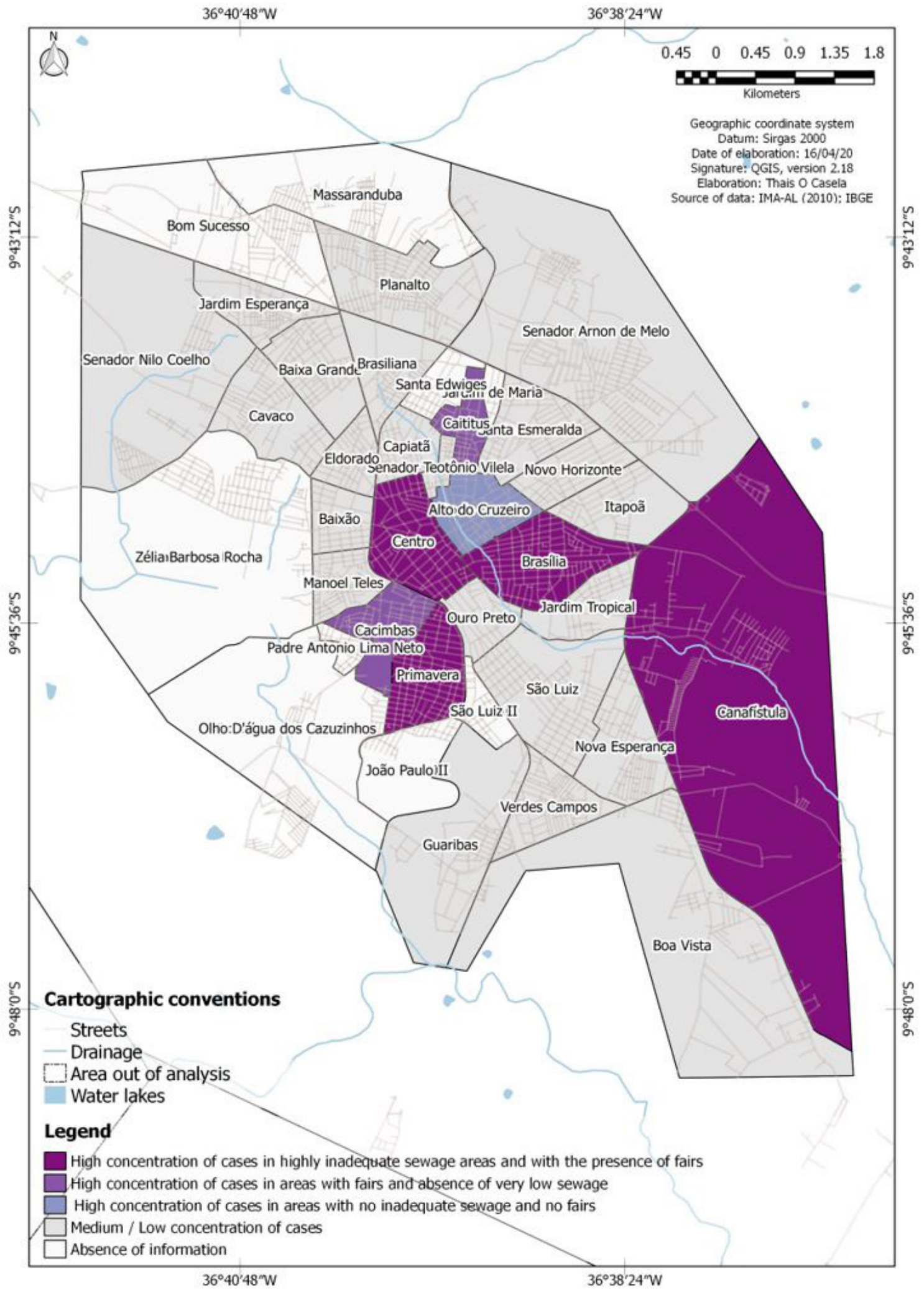

Figure 2. Analysis of scorpionic accidents between the years 2008 to 2018 in the neighborhoods of Arapiraca-AL. 
domestic activities, which are more subject to contact with the scorpion. These data are in accordance with that described in the literature for other regions of the country (Nodari et al., 2006; Nunes et al., 2000).

The most frequently affected anatomical sites were the extremities, especially foot and hand, confirming information obtained in other studies (Pinheiro de Santana et al., 2015; Quadros et al., 2014; Oliveira et al., 2012). Generally, the scorpion attack is unintentional, occurring when touching the hand or foot against the animal, highlighting the risk of walking barefoot, not wearing gloves to manipulate objects and wearing shoes without prior observation (Zanella et al., 2018).

The terrible conditions of sanitation in Arapiraca can also be verified throughout the State of Alagoas. Ribeiro (2014) demonstrates that in the Northeast, Alagoas is only ahead of the states of Maranhão and Piauí in terms of sanitary sewage. In the state of Alagoas, in 2008, only $9.6 \%$ of households had a sewage system. For the author, this may be the factor that made Alagoas the state of the Northeast with the highest occurrence of scorpianism in the period from 2000 to 2009, with an average incidence of $82.5 / 100,000$ inhabitants. It is noteworthy that only 2 neighborhoods in Arapiraca, Manoel Teles and Verdes Campos, corresponded to $20-40 \%$ of inadequate sanitation (IBGE, 2019).

Lira da Silva et al. (2009) investigated cases of scorpionic accidents in the municipality of Salvador, with the research covering the period from 1982 to 2000 . They realized that the most common species was Tityus stigmurus with $64.1 \%$ of the cases, highlighting the good adaptive capacity of the species to the urban environment. He noticed an increase in the number of stings in the 90s, attributing three factors to the increase: 1- disorganized urban growth in the city of Salvador; 2- low socioeconomic conditions in some neighborhoods; 3 - the greater knowledge of the population regarding the data collection service.

Mesquita et al. (2015) who evaluated this reality in the state of Sergipe, found that in this location the increasing number of cases may be related to the way of data collection, with the increase starting in 2008 , also arguing that the The increase may be occurring due to the disorderly growth of urban areas, associated with poor housing conditions and basic sanitation.

Arapiraca has undergone a verticalization process and it is very common to find, in neighborhoods close to the center, solid residues from reforms. It is known that such debris contributes to the increase in temperature, coupled with the fact that the city's sparse afforestation and residences are not suitable for air circulation. In addition, Arapiraca is characterized by being a horizontal city with precarious shading (Silva, 2019).

Another aggravating factor for the increase in cases of scorpionic accidents is the occurrence of street market in some neighborhoods (Centro; Baixão; Brasília; Primavera; Itapuã; Senador Teotônio Vilela; Jardim Esperança and Canafístula) in the municipality of Arapiraca, and depending on the neighborhoods, a large amount of garbage is produced from this. economic activity (IBGE, 2019). these residues remain on the streets for long periods. In addition, the collection of domestic waste is not done daily, being carried out for days, shifts and zoning (urban / rural), alternately, depending on the location of the neighborhoods (Arapiraca, 2019).

The data obtained show that the climatic variables, in the Northeast region, are not a major factor for scorpionism, highlighting that in the regions where the seasons are more defined, it is possible to notice a greater variation in the number of cases. Studies corroborate the results obtained in the studies by Lira da Silva et al. (2009) and Abroug et al. (2015). In these studies it was found that the cases were well distributed over the years, with small variations between months. The influence of climatic variations and seasons interfere more in the South and Southeast regions as highlighted (Lourenço, 2016).

In our research, the little variation between months can be attributed to the climatic conditions of the studied region, which is characterized by an average annual temperature of $28^{\circ} \mathrm{C}$. In addition, the temperature in this region varies little between summer and winter, especially when compared to the South and Southeast regions. This stable climatic condition favors the reproduction of scorpions, leading to the occurrence of cases throughout the year. So, preventive actions against scorpion stings must be carried out during all months of the year.

Furtado et al. (2016) understands that the risk of scorpionism is inherent to routine domestic activities, with a significant impact on children, who are at higher risk of death than adults. It also explains that in some countries most cases of scorpionism occur in rural areas, as in Iran and Mexico, showing that there is a difference in the area where accidents occur between Brazil and other countries.

It is common to find garbage scattered throughout its green area, especially on days of cultural events, even though there are public dumpsters available to the population. The residues are spread for days until the city hall cleans the place. The lack of environmental education of residents has contributed to the worsening of the city's pollution.

For Philippi Junior et al. (2014) it is necessary to invest in the population's environmental education, which is the key to an effective environmental management, both in urban and rural areas, as it is necessary to raise the level of education of the local population for such effectiveness to occur. He adds that the concepts of health, public health, sanitation and the environment are linked. That is why these sciences are currently studied together, forming new branches of human knowledge. The sum of this knowledge originated the term environmental health, since human activities and factors linked to socioeconomic and environmental conditions can potentiate the cases of diseases, deaths and injuries, especially among vulnerable groups such as needy populations, women and children.

Corroborating with the understanding of Philippi Junior et al. (2014) highlight the need for public management to devote attention to basic sanitation factors, water and sewage treatment, rainwater drainage and solid waste collection. They explain that disposal of waste in inappropriate places can bring epidemics as historically the rat flea was responsible for bubonic plague during the Middle Ages. 
For all the reasons raised, it is understandable to understand why the increase in scorpion accidents in the municipality. Anthropic factors and the omission of public power, highlighting the lack of public policies aimed at cleaning the city and raising public awareness, have contributed to perfect habitat conditions for the scorpion, whether due to the accumulated dirt in wasteland existing throughout the city.

The analysis of scorpionism in the municipality of Arapiraca, through data on inadequate sanitation and the presence of open markets, considered possible iterations between these variables by neighborhoods, in order to highlight only the vulnerabilities existing in the region in question. The research brought a lot of information about the Arapiraquense city and how it is propitious for cases of scorpionism. There is no doubt about its importance to the state's economy. Nevertheless, important data were analyzed in order to demonstrate that the municipality needs to create mechanisms to become sustainable, since it grows in a disorganized manner.

The research object was to understand which socioenvironmental factors are contributing to the occurrence of scorpionism in the city in the period of 10 years, 2008 to 2018 , using SINAN as the source of the data. The population and the government itself are also responsible for the increase in the increase in scorpion cases. Garbage could be seen scattered on the streets and squares of the city, even though there were garbage dumps for the deposit of such materials.

In conclusion, regarding the cases of scorpionic accidents, the Arapiraca-AL municipality registered a high number of cases in the last 11 years. It was evident that during the study period there was no statistical relationship when climatic factors were correlated to scorpionic accidents. In turn, when verifying the results of the geoprocessing analysis, it was seen that anthropic factors have been motivating the potential for the occurrence of these accidents, possibly due to the lack of environmental education associated with the lack of public policies. Finally, there is a need to carry out environmental education campaigns aimed at reducing the number of scorpion accidents in Arapiraca-AL.

This study, although it has a large sample covering a period of 11 years, presents limitations because it is a database analysis and it is subject to errors during the entry of information and underreporting. Therefore, the characteristics of scorpionism in Arapiraca-AL still need to be evaluated in later studies that should allow a more accurate analysis of the incidence associated with georeferencing, in addition to the identification of the most frequent scorpion species in the municipality of Arapiraca-AL.

\section{References}

ALBUQUERQUE, I.C.S., ALBUQUERQUE, H.N., ALBUQUERQUE, E.F., NOGUEIRA, A.S. and CAVALCANTI, M.L.F., 2004. Escorpionismo em Campina Grande-PB. Revista de Biologia e Ciências da Terra, vol. 4, no. 1, pp. 1-9.
ABROUG, F., SOUHEIL, E., OUANES, I., DACHRAOUI, F., FEKIHHASSEN, M. and OUANES BESBES, L., 2015. Scorpion-related cardiomyopathy: clinical characteristics, pathophysiology and treatment. Clinical Toxicology, vol. 53, no. 6, pp. 511-518. http:// dx.doi.org/10.3109/15563650.2015.1030676. PMid:25851549.

ARAPIRACA. Prefeitura de Arapiraca, 2019 [viewed 1 October 2019]. Feiras Livre de Arapiraca [online]. Prefeitura de Arapiraca. Available from: http://web.arapiraca.al.gov.br/servicos/feira-livre

BARBOSA, I.R., DE MEDEIROS, W.R. and COSTA, I.C.C., 2015. Distribuição espacial dos acidentes por animais peçonhentos no estado do rio grande do norte-brasil no período de 2001-2010. Caminhos de Geografia, vol. 16, no. 3, pp. 55-64.

BRASIL. Ministério da Saúde, 2018 [viewed 4 April 2020]. SINAN: Sistema de Informação de Agravos de Notificação [online]. Brasília: DATASUS. Available from: http://tabnet.datasus.gov. br/cgi/tabcgi.exe?sinannet/cnv/animaisAL.def

BRASIL. Ministério de Minas e Energia, 2017 [viewed 12 July 2019]. Companhia de Pesquisa de Recursos Minerais. Relatório de Gestão do Exercício de 2017 [online]. Brasília: Ministério de Minas e Energia. Available from: http://www.cprm.gov.br/publique/ media/informacao_publica/relatorio_de_gestao_2017.pdf

CALDERÓN-ARANDA, E.S., DEHESA-DÁVILA, M., CHAVEZ-HARO, A. and POSSANI, L.D., 1996. Scorpions stings and their treatment in Mexico. Envenomings and their treatments. Lyon, France: Editora Fondation Marcel Mérieux, p. 311-320.

CARMO, E.A., NERY, A.A., JESUS, C.S. and CASOTTI, C.A., 2016. Internações hospitalares por causas externas envolvendo contato com animais em um hospital geral do interior da Bahia, 2009-2011. Epidemiologia e Serviços de Saúde : Revista do Sistema Unico de Saúde do Brasil, vol. 25, no. 1, pp. 105-114. PMid:27861683.

CARVALHO, J.C., CARDOSO, P., CRESPO, L.C., HENRIQUES, S., CARVALHO, R. and GOMES, P., 2011. Biogeographic patterns of spiders in coastal dunes along a gradient of mediterraneity. Biodiversity and Conservation, vol. 20, no. 4, pp. 873-894. http:// dx.doi.org/10.1007/s10531-011-0001-8.

CASELA, T.O., 2019. Áreas potenciais para cultivo de eucalipto na região hidrográfica São Miguel, Alagoas. Maceió: Universidade Federal de Alagoas, 109 p. Dissertação de Mestrado em Geografia.

CRUZ, C.D., 2016. Genes Software-extended and integrated with the R, Matlab and Selegen. Acta Scientiarum. Agronomy, vol. 38, no. 4, pp.547-552. http://dx.doi.org/10.4025/actasciagron.v38i3.32629.

DABO, A., GOLOU, G., TRAORÉ, M.S., DIARRA, N., GOYFFON, M. and DOUMBO, O., 2011. Scorpion envenoming in the north of Mali (West Africa): epidemiological, clinical and therapeutic aspects. Toxicon, vol. 58, no. 2, pp. 154-158. http://dx.doi.org/10.1016/j. toxicon.2011.05.004. PMid:21605586.

DIAS, C. and BARBOSA, A.M., 2016. Aspectos epidemiológicos dos acidentes com escorpiões nos municípios de Taubaté e adjacentes. Revista Ciencias de la Salud, vol. 1, no. 3, pp. 8-15.

FRACOLLI, L.A., 2017. Acidentes por escorpiões no estado de São Paulo: uma abordagem sociodemográfica. Revista Uningá, vol. 18, no. 1, pp. 161-174.

FURTADO, S.S., BELMINO, J.F.B., DINIZ, A.N.G.Q. and LEITE, R.S., 2016. Epidemiology of scorpion envenenomation in the state of Ceará, northeastern Brazil. Revista do Instituto de Medicina Tropical de São Paulo, vol. 58, no. 15. http://dx.doi.org/10.1590/ S1678-9946201658015.

GOMES, L., 2012. Modelagem de variáveis qualitativas por meio de redes neurais artificiais: avaliação do uso de análise de correspondência como técnica de codificação. Juiz de Fora: Universidade Federal de Juiz de Fora, 109 p. Dissertação de Mestrado em Modelagem Computacional. 
INSTITUTO BRASILEIRO DE GEOGRAFIA E ESTATÍSTICA - IBGE, 2019 [viewed 30 July 2019]. Comitê de Estatísticas Sociais: Sistema de Informações de Agravos de Notificação - SINAN [online]. Rio de Janeiro: IBGE. Available from: https://ces.ibge.gov.br/ base-de-dados/metadados/ministerio-da-saude/sistema-deinformacoes-de-agravos-de-notificacao-sinan.html

INSTITUTO BRASILEIRO DE GEOGRAFIA E ESTATÍSTICA - IBGE, 2017 [viewed 12 July 2019b]. Arapiraca [online]. Rio de Janeiro: IBGE. Available from: https://cidades.ibge.gov.br/brasil/al/ arapiraca/panorama

INSTITUTO NACIONAL DE METEOROLOGIA - INMET [online], 2016 [viewed 30 July 2019]. Available from: http://www.inmet. gov.br/portal/

LIRA DA SILVA, R.M., AMORIM, A.M., CARVALHO, F.M. and BRAZIL, T.K., 2009. Acidentes por escorpião na cidade do Salvador, Bahia, Brasil (1982-2000). Gazeta Médica da Bahia, vol. 79, no. 1, pp. 43-49.

LOURENÇO, W.R., 2016. Scorpion incidents, misidentification cases and possible implications for the final interpretation of results. The Journal of Venomous Animals and Toxins Including Tropical Diseases, vol. 22, no. 21, pp. 1. http://dx.doi.org/10.1186/ s40409-016-0075-6. PMid:27398081.

MARADEI-IRASTORZA, I., 1999. Scorpion envenomation in Lara State, Venezuela: a historical perspective. The Journal of Venomous Animals and Toxins, vol. 5, no. 1, pp. 104. http:// dx.doi.org/10.1590/S0104-79301999000100020.

MESQUITA, F.N.B., NUNES, M.A.P., SANTANA, V.R., NETO, J.M., ALMEIDA, K.B.S. and LIMA, S.O., 2015. Acidentes escorpiônicos no Estado de Sergipe-Brasil. Revista da Faculdade de Ciências Médicas de Sorocaba, vol. 17, no. 1, pp. 15-20.

NODARI, F.R., LEITE, M.L. and NASCIMENTO, E., 2006. Aspectos demográficos, espaciais e temporais dos acidentes escorpiônicos ocorridos na área de abrangência da $3 a$ Regional de Saúde - Ponta Grossa, PR, no período de 2001 a 2004. Publicatio UEPG. Ciências Biológicas e da Saúde, vol. 12, no. 1, pp. 15-26.

NUNES, C.S., BEVILACQUA, P.D. and JARDIM, C.C.G., 2000. Aspectos demográficos e espaciais dos acidentes escorpiônicos no Distrito Sanitário Noroeste, Município de Belo Horizonte, Minas Gerais, 1993 a 1996. Cadernos de Saude Publica, vol. 16, no. 1, pp. 213223. http://dx.doi.org/10.1590/S0102-311X2000000100022. PMid:10738166.
OLIVEIRA, H. F. A. DE, LOPES, Y. A. C. F., BARROS, R. M., VIEIRA, A. A. and LEITE, R. DE S., 2012. Epidemiologia dos acidentes escorpiônicos ocorridos na Paraíba- Nordeste do Brasil. BioFar, vol. 8, no.2, pp. 86-96.

PHILIPPI JÚNIOR, A., ROMÉRO, M.A. and BRUNA, G.C., 2014. Curso de gestão ambiental. 2. ed. Barueri: Manole.

PINHEIRO DE SANTANA, V.T., BARROS, J.O. and SUCHARA, E.A., 2015. Aspectos clínicos e epidemiológicos relacionados a acidentes com animais peçonhentos. Revista de Ciências Médicas e Biológicas, vol. 14, no. 2, pp. 153-159. http://dx.doi. org/10.9771/cmbio.v14i2.13079.

QUADROS, R.M., VARELA, A.R., CAZARIN, M.G. and MARQUES, S.M.T., 2014. Scorpion envenomations notified by SINAN in the mountainous region of Santa Catarina, Brazil, 2000- 2010. Revista Eletrônica de Biologia, vol. 7, no. 1, pp. 96-108.

RECKZIEGEL, G.C. and PINTO-JUNIOR, V.L., 2014. Análise do escorpionismo no Brasil no período de 2000 a 2010. Revista Pan-Amazônica de Saúde, vol. 5, no. 1, pp. 67-68. http://dx.doi. org/10.5123/S2176-62232014000100008.

RIBEIRO, L. C., 2014. Acidentes escorpiônicos no Nordeste do Brasil: análise epidemiológica de 136.728 casos notificados de 2000 a 2009. Salvador: Universidade Federal da Bahia, 81 p. Dissertação de Mestrado em Saúde Coletiva.

SILVA, M. F. , 2019. Estratégias bioclimáticas para seis cidades alagoanas: contribuições para a adequação da arquitetura ao clima local. Maceió: Universidade Federal de Alagoas, 185 p. Dissertação de Mestrado em Arquitetura e Urbanismo.

SILVA, T. M. A. S., TELES, D. M., BRAGA, P. E. T., AGUIAR, F. C. D. E. and FREIRE, J. E., 2015. Epidemiologia dos acidentes por escorpiões no Ceará no período de 2009 a 2012. Revista Saúde.com, vol. 11, no. 3, pp. 314-323.

SOUZA, C. M. and BOCHNER, R., 2019. Escorpionismo no Rio de Janeiro: contribuições da ciência cidadã para o aprimoramento das políticas de atenção em saúde. P2P E Inovação, vol. 6, pp. 33-49. Edição Especial Informação em Saúde.

STROPA, A.A., 2010. Effect of architectural angularity on refugia selection by the brown spider, Loxosceles gaucho. Medical and Veterinary Entomology, vol. 24, no. 3, pp. 273-277. http:// dx.doi.org/10.1111/j.1365-2915.2010.00888.x. PMid:20572931.

ZANELLA, D.P., VALADÃO, A.F., ARÊDES, C.A.M., CAMPOS, G.C.T., CORDEIRO, N.D.B. and SPENCER, P.J., 2018. Escorpionismo no Vale do aço, Minas Gerais. Brazilian Journal of Surgery and Clinical Research, vol. 23, no. 1, pp. 60-66. 